\title{
COMPARATIVE STUDIES ON OOGENESIS AND PRESPERMATOGENESIS IN THE WISTAR RAT UNDER NORMAL AND PATHOLOGICAL CONDITIONS
}

\author{
W. HILSCHER and Barbara HILSCHER \\ Institut für Lufthygiene und Silikoseforschung an der Universität Düsseldovf, \\ 4, Düsseldorf, Gurlittstrasse 53 (B. R.D.)
}

\begin{abstract}
SUMMARY
Comparative studies of oogenesis and prespermatogenesis show that oogonia are the population parellel to the dividing gonocytes (I-gonocytes), and that oocytes correspond to the resting gonocytes (II-gonocytes). Contrary to oocytes, which pass through the characteristic stages of meiotic prophase, the II-gonocytes do not show any conspicuous morphological changes. After the oocytes have passed a relatively short G-I phase, they enter the S-phase prenatally in preleptotene stage between days $\mathrm{I} 7$ and $\mathrm{r} 8$ of gestation. On the other hand, II-gonocytes spend a very long G-I phase of about 7-9 days before entering the S-phase from postnatal day 3 onwards. The duration of the S-phase of II-gonocytes, determined by double labeling with ${ }^{14} \mathrm{C}$ and ${ }^{3} \mathrm{H}$-thymidine, is found to be about II.5 hours. The duration value of the S-phase of the oocytes, determined by the same method, is comparable to that of the II-gonocytes. Myleran (Busulfan), administered i.p. at day I 4, I5, or I6 of gestation, destroys oogonia and I-gonocytes; when given between days I 7 and $2 I$ of gestation, it reduces the number of supporting cells. II-gonocytes are also very sensitive to Myleran, and a large number of them degenerate from postnatal day 5 onwards.
\end{abstract}

\section{INTRODUCTION}

In a recent report, BAKER (I972) mentions that precise comparative counts of the germ cells in fetal ovaries and testes of mammals have only been done on rat (BEAUMONT and MANDL, I962, I963).

The present study is motivated by a scheme of MAULÉon (page I29, I967). Comparing the scheme of MAULÉON with recent studies on the kinetics of gonocytes (HILscher et al., r972 a), it is found that oogonia in the rat are the population parallel to the dividing gonocytes, whereas the oocytes are the parallel cells of the resting gonocytes (fig. I). In the present study, the dividing gonocytes are called I-gonocytes, and the resting gonocytes, II-gonocytes. 
Experiments with one of the cytostatic drugs, Myleran, reveal that the vulnerability of oogonia is very similar to that of I-gonocytes. When Myleran is injected i.p. in a single dose on days $I_{4}, I_{5}$ and $I_{6}$ of gestation (fig. I) (when the germ cells

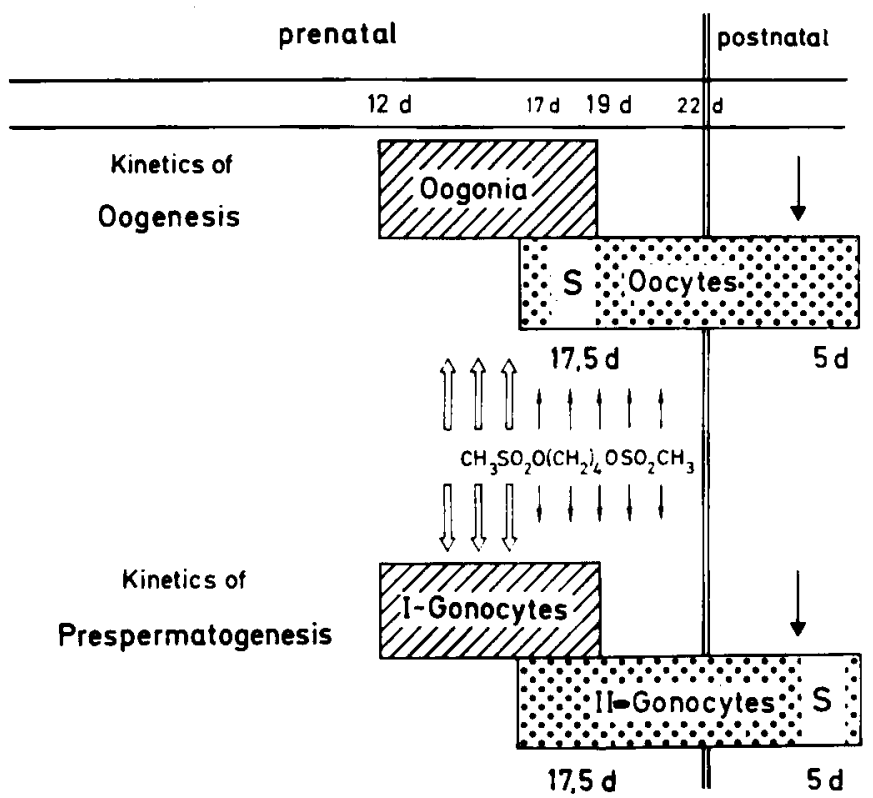

FIG. I. - Model of the kinetics of oogenesis and prespermatogenesis (modification of the scheme of MAULEON, page 129, 1967). Oocytes enter the dictyate stage at the same time as II-gonocytes enter the S-phase (large dark arrows). Myleran, administered at the 14th, 15th and 16th day p.c. (light arrows) destroys ogonoia and I-gonocytes. Administered between the 17th and 21st day p.c. (small dark arrows) Myleran seems to be of no effect to oocytes and II-gonocytes.

Fig.j]. - Cinétique de l'ovogenèse et de la préspermatogenèse. Les ovocytes atteignent le stade dictyé aulmoment où les gonocytes II entrent en phase $S$ (grandes flèches noires). Le Myleran injecté les I4, ${ }_{15}$ et I $6^{\mathrm{e}}$ jour p.c. (flèches blanches) détruit les ovogonies et les gonocytes I. Injecté entre I7 et 2 I jours p.c. (petites flèches noires) le Myleran ne semble pas avoir d'effet sur les ovocytes et les gonocytes II.

are multiplying), the ovaries and testes of 22 day-old fetuses do not reveal the presence of germ cells. When Myleran is injected i.p. in a single dose between days I7 and $2 \mathrm{I}$ of gestation (fig. I) (when oocytes and II-gonocytes are developing), both types of germ cells are encountered in the gonads examined in 22 day-old fetuses. However, in contrast to the gonads of the female fetuses which appear rather unaffected, the male gonads show a very strange aspect. The sex cords are packed with IIgonocytes, whereas the number of supporting cells is extremely reduced (HILSCHER et $a l .$, I972 $b, c)$. These results are in agreement with those of Courot (I964), who found that the supporting cells in the testes of the very young lamb are very sensitive to X-rays. He also described an increase in the number of gonocytes per crosssection of the cords, and pointed out that this increase is only relative and there is no variation in the total number of gonocytes in the testis as a whole.

The present paper presents : I) a quantitative analysis of the effect of Myleran in the prenatal period of oogenesis and prespermatogenesis ; 2) a report on the findings in the sex cords and tubules of immature rats receiving Myleran pre- and postnatally ; 3) some details on the S-phase of oocytes and II-gonocytes. 


\section{MATERIAL AND ME'THODS}

The ovaries and testes of the fetuses and immature rats (Wistar-WU) were fixed in Bouin solution ; sections were prepared at $3 \mu \mathrm{m}$ and stained with hemalum and eosin.

r. Eight pregnant rats received i.p. a single dose of Myleran between days I4 and $2 \mathrm{I}$ of gestation ( $5 \mathrm{mg}$ per $\mathrm{kg}$ body weight at days $\mathrm{I} 4$ and I 5 ; IO $\mathrm{mg}$ per $\mathrm{kg}$ body weight at days I6, I7, I8, I9, 20 and 2 I). The pregnant rats and fetuses were sacrificed on day 22 of gestation. The ovaries of 22 fetuses and the testes of 36 fetuses were quantitatively analyzed. The values were each compared with those of 5 controls. From each animal the quantitative relationship of oocytes to I ooo somatic cells, or of It-gonocytes to I ooo supporting cells, was calculated. The crude counts are not adjusted to true counts.

2. Two pregnant rats received i.p. a single dose of Myleran on day 18 of gestation (2.5 mg per $\mathrm{kg}$ body weight). The male rats of the first litter were sacrificed at day $\mathrm{r}_{3}$, and those of the second litter at postnatal day 25.

3. Male rats of four litters received i.p. a single dose of Myleran (ro mg per $\mathrm{kg}$ body weight), and were sacrificed at postnatal days $5,20,25$ and 30 .

4. Ovaries derived from thirteen litter-groups (seven fetal, six neonatal) were used for histological studies and quantitative analysis of the germ cells. Quantitative studies were carried out on a total of 48 specimens, derived from 25 fetuses and 23 immature rats aged between 16 days $p . c$. and 5 days $p . p$. I ooo germ cells per ovary were identified as oogonia and oocytes in different stages, and the average values per litter were determined.

5. I 8 male rats from four litters were injected i.p. with $1.25 \mu \mathrm{Ci}^{14} \mathrm{C}$-thymidine, and 4 hours later injected with $25 \mu \mathrm{Ci}^{3} \mathrm{H}$-thymidine. The animals were sacrificed one hour after the second injection. 9 animals of two litters received the second injection at 4.5 days, 5 animals of the third litter at 5.0 days, and 4 animals of the fourth litter at 5.5 days. In one testes of each animal, I ooo labeled II-gonocytes were counted and divided into gonocytes labeled only by ${ }^{3} \mathbf{H}$, those labeled only by ${ }^{14} \mathrm{C}$, and those labeled by both ${ }^{14} \mathrm{C}$ and ${ }^{3} \mathrm{H}$. A distribution frequency of the nuclei of II-gonocytes was made, corresponding to that of oocytes described below, from one of the animals receiving the second injection 5.0 days $p$. $p$.

6. Two pregnant animals were first injected with $100 \mu \mathrm{Ci}^{14} \mathrm{C}$-thymidine per $300 \mathrm{~g}$ body weight and 4 hours later were given a second injection of 2 ooo $\mu \mathrm{Ci}^{3} \mathrm{H}$-thymidine per $300 \mathrm{~g}$ body weight. One hour after the second injection, the pregnant animals and the fetuses were sacrificed. The fetuses were serially sectioned and the slides with ovaries stained with hemalum and eosin. To distinguish the oocytes with certainty from oogonia, the following procedure was carried out: As many as $\mathrm{I}$ ooo oocytes in all stages of development in the ovary sections were numbered serially in the corresponding photographs. The diameter of the oocyte nuclei was then measured by means of an electronic micro-length measuring instrument Wild/Tesa ; then the autoradiographs (G 5emulsion, Ilford, Essex) were prepared, and the same I ooo serially-numbered oocytes per animal were examined whether they were unlabeled, labeled only with ${ }^{14} \mathrm{C}$ or ${ }^{3} \mathrm{H}$, or double-labeled with ${ }^{14} \mathrm{C}$ and ${ }^{3} \mathrm{H}$-together. To determine the relation between the diameter of nuclei and the kind of labeling, a distribution frequency of the $I$ ooo numbered nuclei of the oocytes of one animal was made.

\section{RESULTS}

I. Table I is based on the crude counts of oocytes and II-gonocytes in relation to the somatic cells and supporting cells in the female and male litter mates which received the Myleran between day $\mathrm{I}_{4}$ and $2 \mathrm{I}$ of gestation. The normal values are given at the top of the table for 22 day-old fetuses. In columns 2 and 5 , the different values are shown for animals receiving the Myleran at different days p.c. and sacrificed in each case at day 22 of gestation. In the male fetuses receiving the Myleran at different days of gestation, the alteration in the relation between II-gonocytes and supporting cells is extremely significant statistically $(P<0.00 \mathrm{r})$, in regard to the control as well as from day to day. Considering the control values in the female 
TABLE I

Effect of injection of myleran during pregnancy on the number of gonocytes and oocytes at 22 nd day of gestation

Effets de l'injection de Myleran pendant la gestation sur le nombre d'ovocytes et de gonocytes à 22 jours de gestation

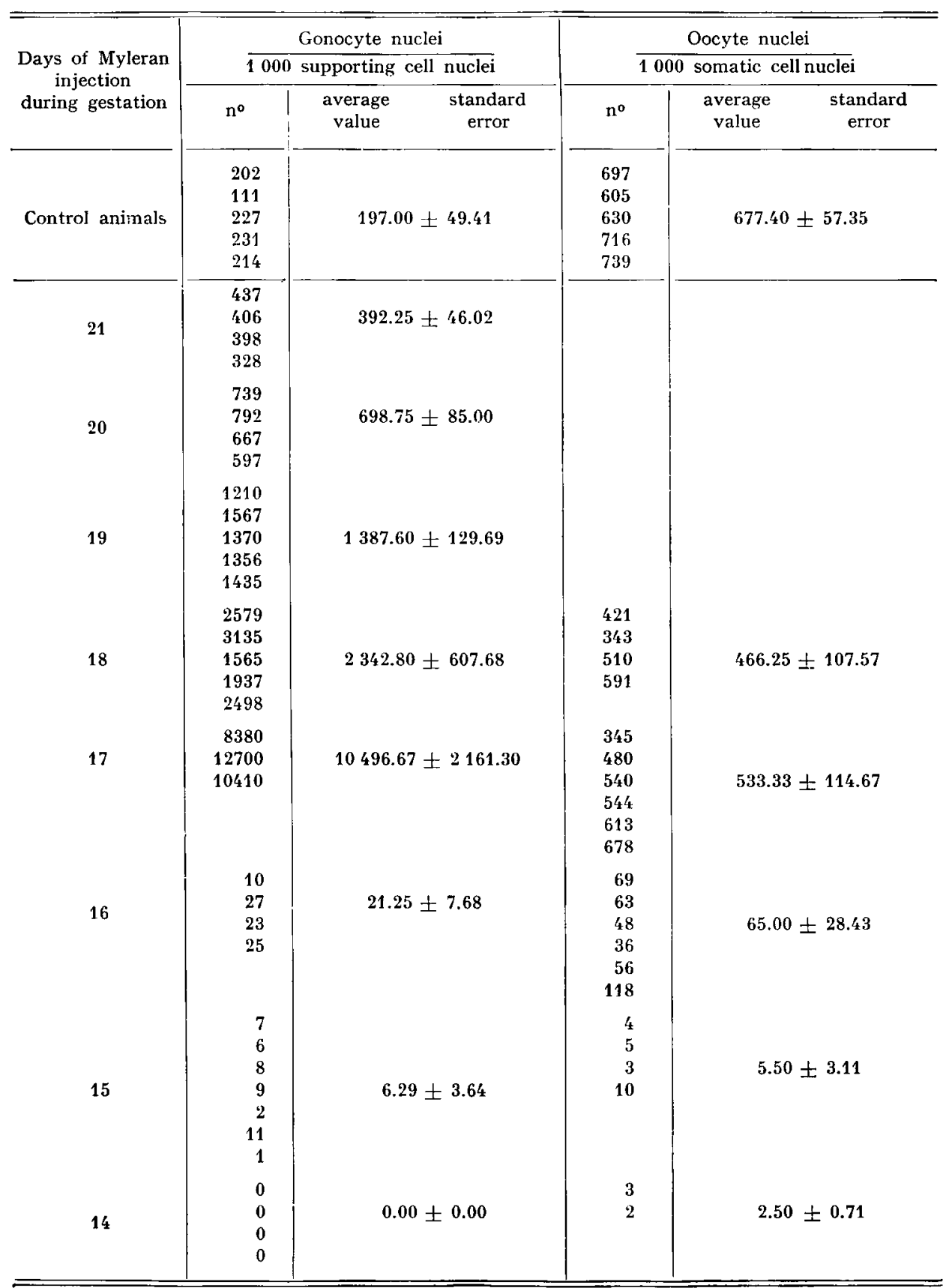


fetuses, there is a statistically significant decrease of the relation between oocytes and somatic cells of the animals which were treated on day $I 8(P<0.0 I)$ and on day $I_{7}(P<0.05)$ of gestation. Furthermore, an extremely significant decrease $(\mathrm{P}<0.00 \mathrm{I})$ can be seen in the relation between oocytes and somatic cells of those animals receiving Myleran at days I6, I5 and I4 of gestation.

2. The aspect of the seminiferous tubules of the $I_{3}$ day-old male litter mates which were given the Myleran at day I8 of gestation, reveals a retardation of spermatogenesis. Whereas the tubules of normal controls at this age always contain a dense layer of spermatocytes, besides supporting cells, the tubules of the treated animals contain a few degenerating II-gonocytes in mitosis and in interphase with swollen or pycnotic nuclei and some immature A-spermatogonia. 25 days after birth, all the tubules of the six male litter mates reveal the presence of spermatogonia. Besides this, spermatocytes are present in many seminiferous tubules.

3. New-born male rats which received the Myleran immediately after birth show a high reduction in the number of supporting cells 5 days $p . p$. On the other hand, most of the II-gonocytes seem to be unaffected. Contrary to the controls, the sex cords of the treated animals reveal the absence of II-gonocyte mitoses. 20, 25 and 3o days after treatment, many tubules contain only supporting cells, but there are also tubules with well-developed seminiferous epithelium consisting of spermatogonia and spermatocytes.

4. Figure 2 shows the evolution of oocytes between $\mathrm{I} 6$ days $p$. $c$. and 5 days p.p. After a relatively short resting stage at days $I 6$ and $I 7$ of gestation, the oocytes

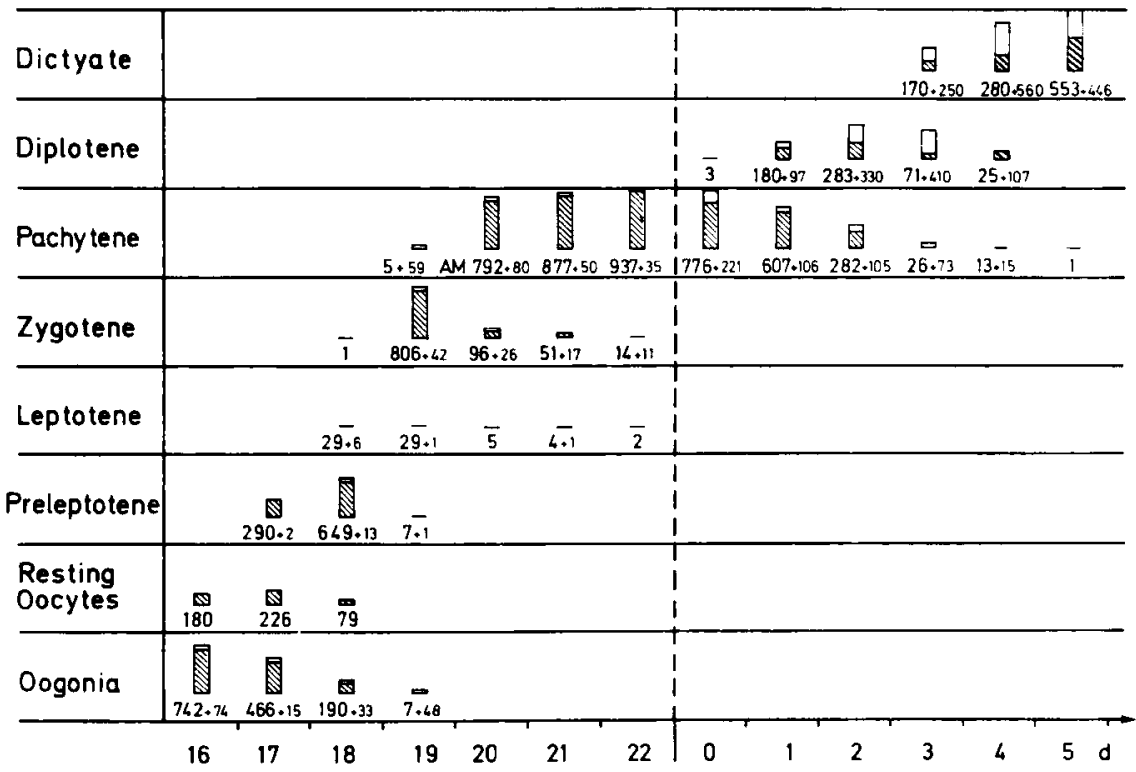

FIG. 2. - Evolution of oogonia and oocytes between the 16th day of gestation and the 5th postnatal day. Large numbers : intact germ cells. Small numbers : degenerating germ cells. Average values of whole litters. AM: Atretic Mitoses.

FIg. 2. - Évolution des ovogonies et des ovocytes entre le $16^{\mathrm{e}}$ jour de gestation et le $5^{\mathrm{e}}$ jour après la naissance. I70 + 250 : cellules germinales intactes + cellules germinales en dégénérescence. Valeurs moyennes par portée. AM : Mitoses Atrétiques. 
enter the preleptotene stage between days I 7 and I8 of gestation. At day I8, oocytes enter the leptotene stage of meiotic prophase. They enter the zygotene stage at day I9, the pachytene stage at day 20 of gestation, the diplotene stage at day I of life, and subsequently the dictyate stage is reached at about day 3 of postnatal life.

5. Table 2 gives the results of the double labeling of II-gonocytes at 4.5 days, 5.0 days and 5.5 days $p . p$. At 4.5 days $p . p$. , there are more II-gonocytes entering the S-phase as compared to the II-gonocytes leaving the S-phase. At 5.5 days $p . p$., the majority of the II-gonocytes have completed DNA synthesis. Therefore, more of the II-gonocytes leaving the S-phase are found as compared to II-gonocytes entering the S-phase. The animals receiving the second injection of ${ }^{3} \mathrm{H}$ thymidine 5 days $p . p$. show a balance in the number of II-gonocytes entering and leaving the $\mathrm{S}$-phase. This means that, as far as the S-phase is concerned, the II-gonocytes are in a steady state at postnatal day 5 . Thus, the duration of the S-phase is derived using the 2 formulas for steady-state systems (HILsCHER et al., I972 a). The duration of the S-phase of II-gonocytes was found to be about II.5 hours.

Figure $3 a$ reveals cumulative percentages of the unlabeled, ${ }^{3} \mathrm{H}$ labeled, ${ }^{14} \mathrm{C}$ labeled and double-labeled nuclei in respect to diameter. The diameters of the unlabeled II-gonocytes, which are in G-I phase, are significantly smaller than those of all types of labeled nuclei. The diameters of the cells in S-phase and G-2 phase show a continuous increase, but the cumulative percentages of the labeled nuclei are not significant.
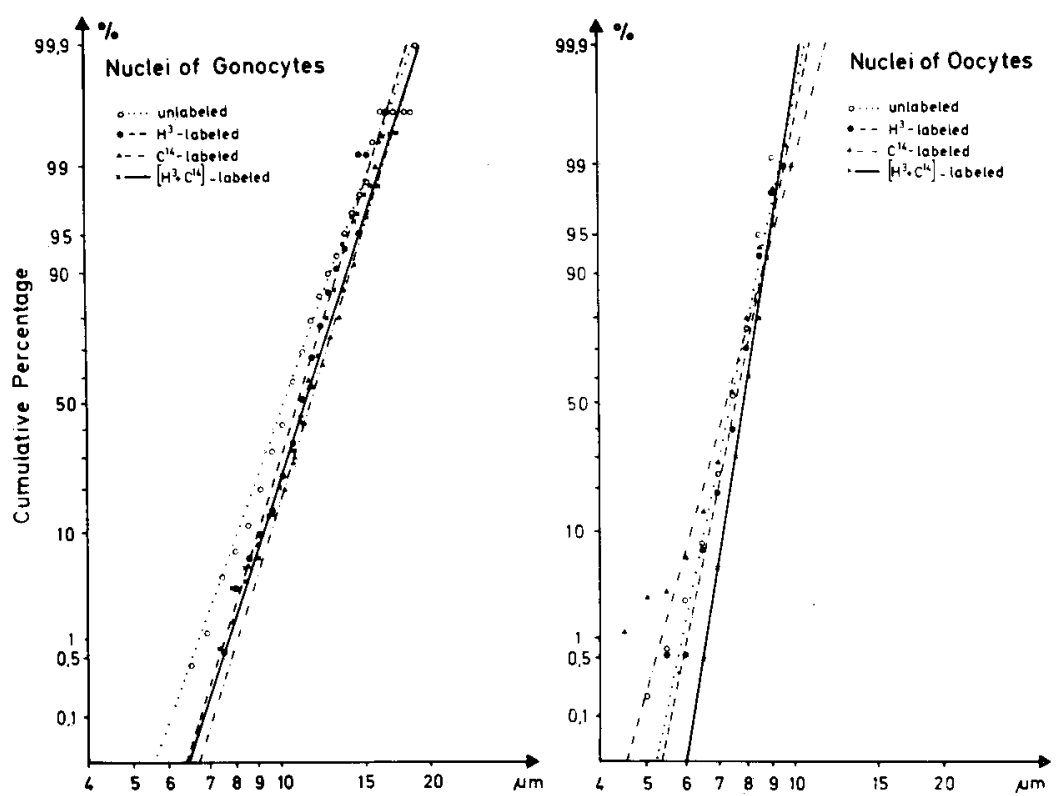

FIG. 3. - The distribution of the diameters of unlabeled, ${ }^{3} \mathrm{H}$ labeled $\left({ }^{3} \mathrm{H}+{ }^{14} \mathrm{C}\right)$-labeled, and ${ }^{14} \mathrm{C}$ labeled nuclei

3 a) II-gonocytes of Wistar rat (5.0 days p.p.)

3 b) Oocytes of Wistar rat ( 17.0 days p.c.)

FIG. 3. - Distribution des diamètres des noyaux non marqués ou marqués

3 a) Gonocytes-II 5 jours p.p.

3 b) Ovocytes I7 jours p.c. 
TABLE 2

Labeling of oocytes and gonocytes by ${ }^{3} \mathrm{H}$-thymidine and ${ }^{14} \mathrm{C}$-thymidine given at 4 hrs interval

Marquage des gonocytes et des ovocytes par la thymidine- ${ }^{3} \mathrm{H}$ et la thymidine- ${ }^{-14} \mathrm{C}$ données à 4 heures d'intervalle

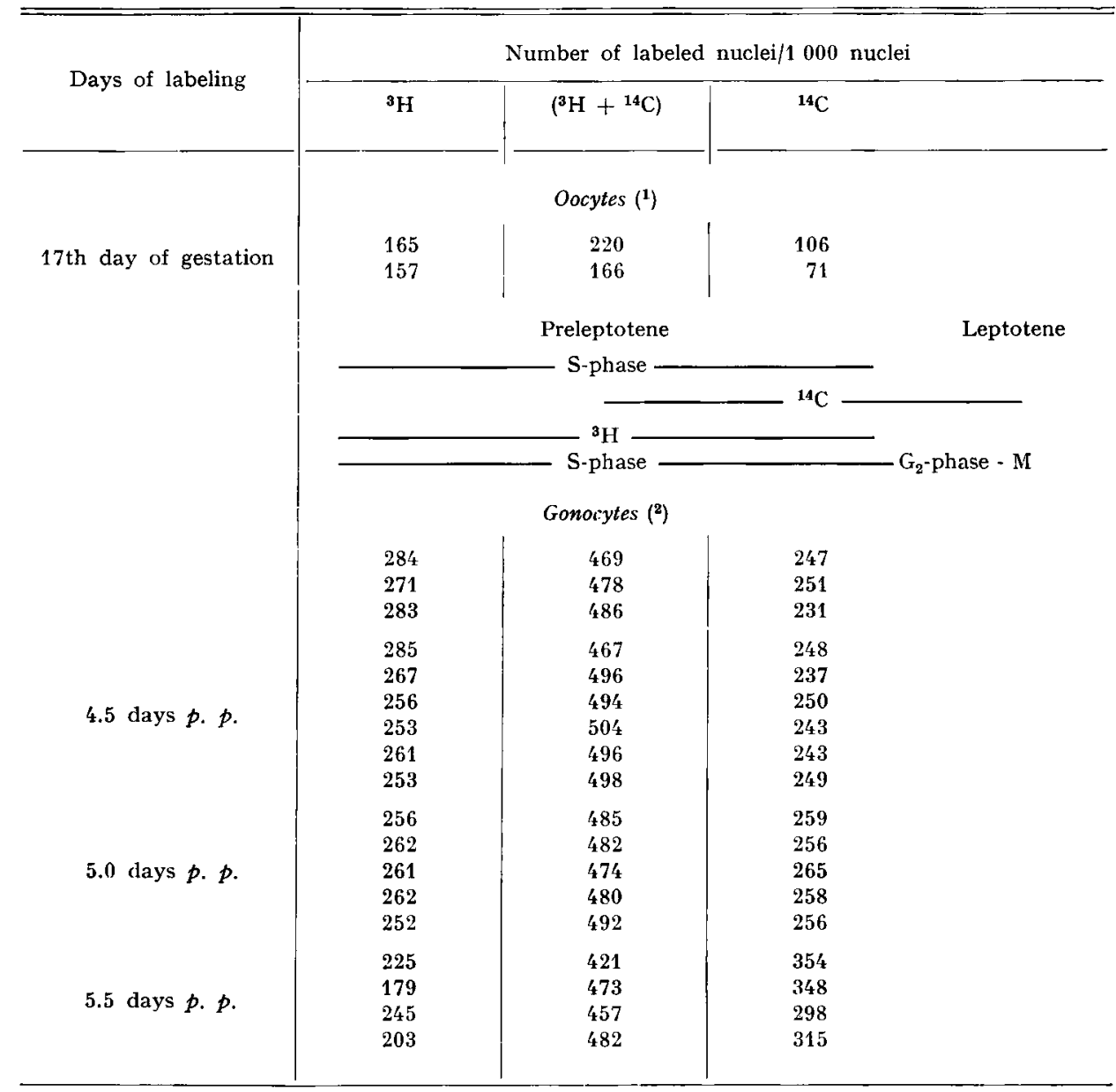

(1) Labeled nuclei/1 000 nuclei (unlabeled and labeled).

(2) Labeled nuclei/1 000 labeled nuclei.

6. Table 2 gives the results of the double labeling of oocytes at day I7 of gestation. The number of oocytes which enter the S-phase within 4 hours is significantly higher than that of the oocytes which have completed the S-phase. As the steady state is not yet reached at day $I 7$ of gestation, it is not possible to know the exact duration of the S-phase. However, an idea of the duration of this oocyte phase can be tentatively ascertained. The values obtained are comparable to those of IIgonocytes. 
Figure $3 b$ reveals the cumulative percentages of the unlabeled, ${ }^{3} \mathbf{H}$ labeled, double-labeled and ${ }^{14} \mathrm{C}$ labeled nuclei of oocytes with regard to diameter. The cumulative percentages of the ${ }^{14} \mathrm{C}$ labeled nuclei show that there are two fractions ${ }^{2}{ }^{14} \mathrm{C}$ labeled oocytes. The nuclei with the small diameters are in early G-I phase and are histologically identified as oocytes in the resting stage before autoradiographs were prepared. They are labeled as oogonia before the last mitoses. The nuclei with the greater diameters belong to the G-2 phase and are passing from the preleptotene stage to the leptotene stage. They are labeled when in the S-phase of the preleptotene stage. Moreover, it should be noted that the diameters of the unlabeled oocytes are smaller than those of the ${ }^{3} \mathrm{H}$ labeled and double-labeled nuclei, and there is an increase in the diameters from the ${ }^{3} \mathrm{H}$ labeled to the double-labeled oocytes. However, the differences are not significant.

\section{DISCUSSION AND CONCLUSIONS}

A comparison between oocytes and II-gonocytes reveals that both cell types arise at the same time (HILscher et al., I972 b,c). Contrary to oocytes, which pass through the characteristic stages of meiotic prophase, the II-gonocytes do not show any conspicuous morphological changes. Their degeneration index is significantly lower than that of oocytes.

Another significant difference between oocytes and II-gonocytes is that they differ from one another at the time of entering the S-phase. After the oocytes have passed through a relatively short G-I phase, they enter the S-phase prenatally in preleptotene stage between days $\mathrm{I} 7$ and $\mathrm{I} 8$ of gestation. On the other hand, IIgonocytes have a very long G-I phase, lasting about 7 to 9 days, before entering the S-phase from postnatal day 3 onwards.

As the oocytes and II-gonocytes pass through different stages of development nearly synchronously, the present study shows that it is important to find out exactly at what time the balance is reached between the cells entering and those leaving the S-phase. The balance of II-gonocytes is reached at 5.0 days $p . p$. The oocytes must be studied further to determine whether the balance of oocytes entering and leaving the S-phase is found at 17.5 or I8.o days $p$. $c$.

The duration of the S-phase of II-gonocytes is about II.5 days. The values obtained for the duration of the oocytes S-phase are comparable to those of II- gonocytes and oocytes in the rabbit and mouse (CRONE et al., I965; PETERs and CRONE, I967).

Concluding the comparison between oocytes and II-gonocytes, it seems that oogenesis ends and folliculogenesis begins as soon as the oocytes enter the dictyate stage, and prespermatogenesis ends and spermatogenesis begins as soon as the IIgonocytes enter mitosis. Furthermore, it is quite apparent that there is a parallelism between the duration of oogenesis and prespermatogenesis in rat (fig. I).

The experiments with Myleran reveal the similarity between oogenesis and prespermatogenesis during the period of mitotic activity of oogonia and I-gonocytes. When Myleran is injected at days I4, I5 and I6 of gestation, the values for oocytes, as well as for II-gonocytes, practically drop to zero at day 22 of gestation since no germ cells, or very few germ cells, can be seen in the ovaries and testes (table I). This means that Myleran has a definite lethal effect on the viability of oogonia 
and I-gonocytes. On the other hand, oocytes and II-gonocytes seem to be resistent to Myleran. There is no quantitative change in the number of oocytes and II-gonocytes when the fetuses receive Myleran at day I7 of gestation or later; but while there is nearly no effect on the somatic cells in the female gonads, the number of supporting cells is extremely reduced in the male gonads. The results show that the effect of Myleran on the supporting cells diminishes from day I7 of gestation onwards (table I). A possible explanation for the vulnerability of the supporting cells may be attributed to an increased rate of proliferation from day I7 to day 22 of gestation. The mitotic index reaches values of about $3 \mathrm{p}$. Ioo between days $2 I$ and 22 of gestation, when it then falls to I.5 p. Ioo between postnatal days I and 5. On the other hand, the mitotic index of the female somatic cells is very low from day $I 7$ of gestation onwards. The mitotic index rises with the beginning of folliculogenesis. Therefore, a possible explanation for the high resistence of the female somatic cells to Myleran could be the low proliferation rate before folliculogenesis begins (HILscher et al., I972 $b, c$ ).

Although II-gonocytes reveal no morphological changes in the first postnatal days, many of them degenerate or become necrotic on approaching mitosis. This is in contrast to the behavior of the oocytes (VANHEMS, I972). One of the tentative explanations for the different vulnerability of oocytes and II-gonocytes may be that they differ from one another at the time of entering the S-phase.

Quantitative studies carried out on the testes of new-born rats after exposure to X-rays (AREFF, I973) are in agreement with the results achieved by Myleran. When the animals receive total body irradiation of $200 r$ immediately after birth, the number of supporting cells is highly reduced in the days following the exposure. Similarly, II-gonocytes seem to be normal up to postnatal day 5, as they are in the tubules of the rats receiving Myleran as new-born animals. However, instead of entering mitosis, II-gonocytes degenerate and become necrotic. Only supporting cells and no germ cells are to be seen in the tubules of 20 and 30 day-old rats, irradiated immediately after birth. As far as the II-gonocytes are concerned, corresponding observations were reported by FranchI and MANDI (Ig66).

\section{ACKNOWLEDGEMENTS}

The expenses incurred in this study were defrayed from grants by the " Deutsche Forschungsgemeinschaft ".

The authors gratefully acknowledge the helpful comments of Professor Dr Werner MAURER, 87 Würzburg, Institut für Medizinische Strahlenkunde der Universität.

\section{RÉSUMÉ}

\section{ÉTUDE COMPARÉE DE L'OVOGENÈSE ET DE LA PRÉSPERMATOGENÈSE \\ CHEZ LE RAT WISTAR \\ DANS DES CONDITIONS NORMALES ET PATHOLOGIQUES}

La comparaison de l'ovogenèse et de la préspermatogenèse dans le fœetus de Rat, montre que la population d'ovogonies est contemporaine de celle des gonocytes en division (gonocytes I) du mâle et que les ovocytes correspondent aux gonocytes " au repos " (gonocytes II). Pendant que 
les ovocytes passent par les stades caractéristiques de la prophase méiotique, l'aspect des gonocytes II ne change pratiquement pas. Après une phase G-I relativement courte, les ovocytes entrent en phase $S$ les jours $I 7$ et $\mathrm{I} 8 \mathrm{de}$ la vie foetale, alors qu'ils sont au stade préleptotène. Au contraire, les gonocytes II ont une phase G-I de longue durée, 7 à 9 jours, et entrent en phase $\mathrm{S}$ à partir du troisième jour après la naissance. La durée de la phase $\mathrm{S}$ des gonocytes II et des ovocytes, déterminée par double marquage à la thymidine ${ }^{3} \mathrm{H}$ et ${ }^{14} \mathrm{C}$ est de I I,5 heures.

L'injection de Myleran entre les jours 14 et $\mathrm{i} 6$ de gestation provoque la destruction des ovogonies et des gonocytes I. L'administration de Myleran du jour 17 au jour $2 x$ de gestation est pratiquement sans effet sur les ovaires. Le même traitement provoque une réduction du nombre de cellules de soutien présentes dans le testicule le jour de la naissance. Les gonocytes II semblent intacts.

Si on administre le Myleran immédiatement après la naissance, les gonocytes II semblent intacts jusqu'au cinquième jour. Ensuite, la plupart des gonocytes II dégénèrent et n'entrent pas en mitose. A zo jours la plupart des tubes séminifères ne contiennent plus que des cellules de soutien, quelques-uns cependant contiennent des spermatogonies et des spermatocytes.

Après administration d'une dose plus faible de Myleran au jour i 8 de la vie foetale, les testicules examinés 13 jours après la naissance, montrent un retard dans l'évolution du testicule : parmi les cellules de soutien et les gonocytes II qui dégénèrent à l'interphase ou pendant la mitose, on trouve seulement quelques rares spermatogonies A. Mais 25 jours après la naissance, bien que l'évolution testiculaire soit toujours retardée, presque tous les tubules contiennent des spermatogonies et des spermatocytes.

\section{REFERENCES}

ARefF A., I973. Störungen der Präspermatogenese durch Röntgenstrahlen. Inaug.-Diss., Düsseldorf.

BAKer G. T., I972. Gametogenesis. Acta Endocr., 71, suppl. I66, 18-4I.

Beaumont H. M., Mandl A. M., rg62. A quantitative and cytological study of oogonia and oocytes in the foetal and neonatal rat. Proc. roy. Soc. B., 155, 557-579.

Beaumont H. M., Mande A. M., I963. A quantitative study of primordial germ cells in the male rat. J. Embryol. Exptl. Morphol., 11, 715-740.

Courot M., I964. Some results obtained in the irradiation with X-rays of testes of lambs. In Effects of Ionizing Radiation on the Reproductive System. W. D. Carlson and F. X. Gassner. eds., p. 279. Pergamon Press, Oxford.

Crone M., Lévy E., Peters H., I965. The duration of the premeiotic DNA synthesis in mouse oocytes. Exp. Cell Res., 39, 678-688.

FRANChI L. L., MANDL A. M., I 966 . The ultrastructure of male germ cells in rats X-irradiated at birth. Proc. Roy. Soc. B., 165, r36-154.

Hilscher B., Hilscher W., Delbrück G., Lerouge-Błnard B., I972. Autoradiographische Bestimmung der S-Phasen-Dauer der Gonocyten bei der Wistarratte durch Einfach- und Doppelmarkierung. Z. Zellforsch., 125, 229-25I.

Hilscher W., HILscher B., Gauss G., I972. Vergleichende Untersuchungen zur Orthologie und Pathologie der Oogenese und Präspermatogenese der Wistarratte. Verh. Dtsch. Ges. Path., 56, 635.

Hilscher W., Hilscher B., Gauss G., Lippers P., BülthofF B., r972. Untersuchungen zur Kinetik der Gonocyten und Stützzellen der Wistarratte unter normalen und pathologischen Bedingungen. Andrologie, 4, 3II-325.

Mauléon P., r967. Cinétique de l'ovogenèse chez les Mammifères. Arch. Anat. Microscop. Morphol. Exptl., 56, Suppl. 3-4, I25-150.

Peters H., Crone M., I967. DNA synthesis in oocytes of mammals. Arch. Anat. Microscop. Morphol. Exptl., 56, I6o-I 70 .

VAnHems E., r972. Action du Misulban sur le développement de l'ovaire de rat. Colloque sur l'ovogenèse et la folliculogenèse. Nouzilly, France, I4 et 15 décembre I972. 